\title{
Unisex Insurance Pricing: Consumers' Perception and Market Implications
}

\author{
Hato Schmeiser, Tina Störmer and Joël Wagner \\ Institute of Insurance Economics, University of St. Gallen, Kirchlistrasse 2, 9010 St. Gallen, Switzerland. \\ E-mails: hato.schmeiser@unisg.ch; tina.stoermer@unisg.ch; joel.wagner@unisg.ch
}

The main reason for different insurance premiums and benefits is the use of different statistically proven risk factors in actuarial calculations for individuals. Basing its ruling on European Union Directive 2004/113/EC, the European Court of Justice on 1 March 2011 concluded that any gender-based discrimination is prohibited, so gender equality in the European Union (EU) must be ensured from 21 December 2012. Until then, gender-specific premium differentiation was allowed in most EU Member States for risks that are strongly linked to gender. We discuss the relevance of price differentiation criteria from the point of view of insurers, regulators and ethicists, and reflect on the degree of acceptance of such price differentiation by consumers, which is assessed empirically through an international consumer survey conducted in the United Kingdom, Germany, France, Italy and Switzerland. The perception of risk factors and of effective genderrelated price differences is considered with respect to motor, annuity, term life and health insurance. Finally, we discuss possible consequences of the new regulation for the insurance industry. The Geneva Papers (2014) 39, 322-350. doi:10.1057/gpp.2013.24

Keywords: insurance pricing; risk criteria; unisex premiums; gender discrimination

Article submitted 11 June 2012; accepted 14 June 2013; published online 4 December 2013

\section{Introduction}

The debate about equal treatment between men and women has a long tradition in Europe and is a fundamental principle of the European Union (EU, para. 4). ${ }^{1}$ The current EU gender equality law is a combination of "Treaty provisions, legislation and the case law of the European Court of Justice" (ECJ) (p. 1). ${ }^{2}$ The origin of gender equality dates back to the Treaty establishing the European Economic Community (EEC) of 1957. Article 119 of the EC Treaty (now, after the entry into force of the Treaty of Lisbon, Article 157 of the Treaty on the Functioning of the EU (TFEU)) enshrines "the principle of equal pay between men and women for equal work" (p. 2). ${ }^{2}$ Not all countries had integrated this Article into their national legislation by 1 January 1962 as planned. A 2011 ruling of the European Court of Justice (ECJ) reaffirmed the fact that there were "a number of existing legal instruments for the implementation of the principle of equal treatment between men and women in matters of employment and occupation" (Section 3, para 15$)^{3}$, for example Council Directive

\footnotetext{
${ }^{1}$ Council of the EU (2004).

${ }^{2}$ Burri and Prechal (2010).

${ }^{3}$ ECJ (2011).
} 
75/117/EEC ${ }^{4}$ and Council Directive 76/207/EEC. In the area of occupational social security schemes, the Council Directive 86/378/EEC was adopted. Further, in the field of pregnancy, motherhood and parental leave, the Council Directive 92/85/EEC, as well as Council Directive 96/34/EC (pp. 13-14) ${ }^{2}$ were set up. In the year 2006, "the Recast Directive 2006/ $54 / \mathrm{EC}$ was adopted in which the existing provisions of different sex equality directives are brought together and some case law of the ECJ is incorporated" (p. 7). ${ }^{2}$

The European Commission decided to extend gender equality to other areas outside the labour market in the Social Policy Agenda because of several cases of jurisprudence of the ECJ (p. 19). ${ }^{5}$ In November 2003 the European Commission presented a proposal for the first Directive outside the area of employment implementing the principle of equal treatment between women and men in the access to and supply of goods and services (p. 1). ${ }^{5}$ Article 1 of the proposal decrees that public goods and services also "include services such as banking, insurance and other financial services" (p. 13). ${ }^{5}$ The Council of the EU adopted Directive 2004/113/EC (hereinafter called the Gender Directive) ${ }^{1}$ on 13 December 2004 in order to implement "a framework for combating discrimination based on sex [...], with a view to putting into effect in the Member States the principle of equal treatment between men and women" (p. 6). ${ }^{5}$ The main reason for a standardised legal framework is "that sex is not the dominant factor in determining life expectancy". Therefore, "different actuarial calculations for determining premiums $[\ldots]$ for insurance products related to life expectancy must be considered as sex discrimination" (p. 7). "However, the Directive allowed various exceptions to the principle of equal treatment" (p. 15). ${ }^{2}$

Article 5(1) of the Gender Directive states: "Member States shall ensure that in all new contracts concluded after 21 December 2007 at the latest, the use of sex as a factor in the calculation of premiums and benefits for the purposes of insurance and related financial services shall not result in differences in individuals' premiums and benefits" (p. 41). ${ }^{1}$ However, Article 5(2) of the Gender Directive reads: "Notwithstanding paragraph 1, Member States may decide before 21 December 2007 to permit proportionate differences in individuals' premiums and benefits where the use of sex is a determining factor in the assessment of risk based on relevant and accurate actuarial and statistical data" (p. 41). ${ }^{1}$ This clause allowed an exception for insurance companies as long as they provide actuarial and statistical data that verify gender as an objective risk-rating factor.

On 1 March 2011, the ECJ issued a ruling on the validity of Article 5(2) of the Gender Directive in a case brought by the Belgium consumer association Test-Achats ASBL and two Belgian citizens against the Conseil des Ministres of Belgium. The Court considered whether Article 5(2) of the Gender Directive was compatible with Article 6(2) of the Treaty on European Union (TEU), "and, more specifically, with the principle of equality and nondiscrimination guaranteed by that provision", and, if the answer to the first question is negative, whether Article 5(2) of the Directive was also incompatible with Article 6(2) of the TEU "if its application is restricted to life assurance contracts" (para. 14). ${ }^{3}$ The ECJ ruled: "Article 5(2) of [the Gender Directive] of 13 December 2004 implementing the principle of equal treatment between men and women in the access to and supply of goods and services is invalid with effect from 21 December 2012". ${ }^{3}$ On this basis, it was not necessary to answer

\footnotetext{
${ }^{4}$ Council of the EC (1975).

${ }^{5}$ Commission of the EC (2003).
} 
the second question (para. 34-35). ${ }^{3}$ In light of the Court's ruling, it is no longer allowed to treat male and female policyholders differently when calculating premiums and benefits for new insurance contracts.

The ruling has led to a broad public discussion within both the insurance industry and insurance associations as well as consumer organisations. The ongoing debate about discrimination illustrates the area of conflict. Most EU Member States applied Article 5(2) and still allowed the use of gender as a risk-rating factor in calculating their insurance products. Therefore, the judgement will impact on all EU Member States (para. 3). ${ }^{6}$ An important aspect of discrimination in insurance is the differentiation between, on the one hand, discrimination law, based on the principle of human rights and the principle of equality among individuals, and, on the other hand, the principle of actuarial fairness and actuarial equality. Hence, the question arises as to whether the customer as an individual feels that he or she is treated fairly and what impact the Gender Directive has on the insurance industry and policyholders.

In addition to the legal texts, many surveys and much literature are concerned with issues of gender differentiation in the insurance industry as well as the price sensitivity of policyholders. In addition to the legal and economic aspects, ethical issues are also often analysed. A survey of the $\mathrm{EU}^{7}$ deals with the theme of ethically justified price differentiation due to different risk characteristics. However, rather than policyholders as insurance customers, this survey interviews and takes account of consumer organisations, ombudsmen and national insurance and banking associations. Ebner (p. 7$)^{8}$ examines differences in the degree of willingness to pay higher premiums among insurance customers as well as their specific behaviour patterns in terms of behavioural pricing, but did not restrict it to the risk criteria of gender. Furthermore, Homburg and Koschate ${ }^{9}$ analyse price sensitivity in different product lines with high demand for insurance that is usually mandatory, for example, motor and life insurance. They conclude, for example, that the respondents do not require the removal of gender differences in pricing if positive effects are expected for the group as a whole. Borenstein ${ }^{10}$ also analyses consumers' behaviour in competitive insurance markets, but focuses on discrimination based on risk sorting in insurance companies. He points out that the soundness of insurance can be enhanced by a ban on several risk classification factors in actuarial pricing (p. 38). ${ }^{10}$ It should be noted that regulatory intervention in actuarial calculation and, in particular, gender differentiation, has been discussed in scientific literature in the U.S. since the 1970s. ${ }^{11}$

${ }^{6}$ European Commission (2012).

${ }^{7}$ Civic Consulting (2010a, b, c).

${ }^{8}$ Ebner (2010).

${ }^{9}$ Homburg and Koschate (2005).

${ }^{10}$ Borenstein (1989).

${ }^{11}$ This followed the initiation of various lawsuits brought by policyholders against the use of gender-specific life tables in actuarial calculations of pension schemes. In the U.S., gender inequality violates Title VII of the Civil Rights Act of 1964. In two decisions-the Manhart case (see U.S. Supreme Court, 1978) and the Norris case (see U.S. Supreme Court, 1983) — the U.S. Supreme Court ruled that pension payments must be equal for both sexes and banned the use of gender-specific life tables. In this context, various authors consider the aspect of gender discrimination in U.S. pension schemes from ethical and economical perspectives (see, for example, Martin, 1977, 1979; Hedges, 1977; Myers, 1977; Kimball, 1979, 1980; Brilmayer et al.,1979, 1983; Laycock and Sullivan, 1981; Benston, 1982, 1983; Christiansen, 1983; Hickman, 1983). Finkelstein et al ${ }^{20}$ (p. 38) analyse regulatory aspects and their consequences for the insurance industry. They develop an equilibrium 
Charges of discrimination mainly relate to ascriptive personality characteristics, for example, gender, ethnic origin or race (p. 229). ${ }^{12}$ In the European literature, for example, Schmidt $^{13}$ discusses discrimination against women in private health insurance. Also Ford and Reifner ${ }^{14}$ consider inequality between sexes in the insurance and financial sector. Buzzacchi and Valletti (p. 71) ${ }^{15}$ analyse in their paper the welfare and impact of strategic price discrimination in mandatory insurance markets. Thiery and Van Schoubroeck (p. 190) ${ }^{16}$ examine aspects of fairness and equality in actuarial risk selection from a legal standpoint and their impact on insurance companies.

So far, the literature and surveys concerned with issues of gender differentiation in the insurance industry and the price sensitivity of policyholders do not take the customer's point of view into account directly, but rather indirectly through, for example, relevant associations' opinions or court rulings. In the following study, we use a survey to investigate consumers' views on the ethical acceptability of price differentiation factors (survey Part I). In the second part of the survey, to link the judgement of the ECJ with the subject of discrimination in insurance, as previously mentioned, we specifically focus on the assessment of price sensitivity for differentiated premiums based on the gender risk criterion. We believe this point is important because - to our knowledge-in the existing recent literature, customers were not asked about their opinion on gender-specific pricing.

Our contribution focuses on core dimensions along the following line of reasoning: First, we examine the customer's perspective by conducting a broad survey covering different insurance products and several European countries. Second, we compare views on and exposure to price calculation in these countries and product lines. Third, we put the gender criterion in context with other relevant differentiation criteria. Finally, we assess consumers' opinions of the fairness of the resulting price differences.

The remainder of the paper is structured as follows. In the next section, we discuss the importance of risk differentiation in pricing in light of varying perspectives of different stakeholders. We present the viewpoints of insurers, regulators and ethicists (section "Perspectives on price differentiation"), as well as the customer's view of price differentiation, which is based on new empirical results from our study (section "Customer perception of risk factors"). In the subsequent section, we focus on the particular case of the gender criterion, that is, the use of gender as a risk factor in different countries and product lines (section "Use of gender in different countries and product lines") and customers' perceptions of price differences due to gender-based differentiation (section "Customer perspective"). In the section "Possible implications of the ban on gender-based discrimination", we sum up the results of the different stakeholder perspectives and discuss possible implications of the EU ban on gender-based discrimination. Therefore, we focus on customers' reactions, the

screening model to show the impact of gender-based pricing restrictions on annuity products based on the papers of Hoy (1982) as well as Crocker and Snow (1986).

12 See, for example, Schiek (2000).

13 Schmidt (1989).

${ }^{14}$ Ford and Reifner (1992).

${ }^{15}$ See Buzzacchi and Valletti (2005).

16 Thiery and Van Schoubroeck (2006). 
reactions of the insurance industry and possible further regulatory intervention. Finally, the last section summarises our findings and presents our conclusions.

\section{Risk differentiation factors in insurance pricing}

Differentiation criteria play an important role in insurers' premium and benefit calculations. In this section, the relevance of risk factors for adequate pricing is analysed from different viewpoints. The insurance industry's goal of price differentiation is to ensure a profitable business model and to avoid adverse selection effects. From the regulatory viewpoint, differentiation through discrimination, for example, based on race or nationality, should be prevented. From an ethical point of view, differentiated premiums may appear to be antisocial and prohibit solidarity in the group of policyholders. Finally, we introduce new empirical results from a consumer survey that illustrate the customer's point of view.

\section{Perspectives on price differentiation}

Insurance industry's point of view

Actuarial calculation of risk differentiation in pricing is based on the principle of equivalence, which is deemed to exist when the present values of premiums and benefits are equal. The statistically expected claims costs depend on risk characteristics and form the basis for a riskadjusted premium calculation (p. 15). ${ }^{17}$ With the help of price differentiation, an insurance company can minimise the effects of anti-selection. ${ }^{18}$ This means the customer portfolio is protected against policyholders leaving because of lower loss expectancy and higher premiums, or taking out a policy because of higher loss expectancy and lower premiums (p. 469). ${ }^{19}$ The more precisely an insurer is able to calculate expected claim payments, the better it can differentiate premiums. Furthermore, this also enables the acquisition of lower-risk customers with adequately lower premiums. This approach minimises crosssubsidisation in the portfolio (p. 41). ${ }^{20}$

On the one hand, differentiation by risk exposure is not discrimination but rather, is indispensable for private insurance to function in a competitive market (p. 95) ${ }^{21}$ On the other hand, high premium differentiation can result in the exclusion of higher-risk policyholders, whose premiums might be raised to an unaffordable level. Thus, the more accurately an insurer can calculate premiums and provide policyholders a fair price, the more

\footnotetext{
17 See, for example, Wang (2000).

18 Adverse selection, also known as anti-selection, describes when an insurer and a policyholder have different information regarding risk. Adverse selection can arise in markets with asymmetric information, where at least one party does not have comprehensive insights into a certain issue (see Rothschild and Stiglitz, 1976, p. 629). Therefore, if a prospective client has more information about his estimated risks of loss than the insurer, he takes out his level of coverage based on this information (Association of British Insurers (ABI), 2010, p. 51). Hence, the customer is interested in policies which cover the individual expected risk of loss, and the insurer is unable to provide him such an individual premium. Several authors deal with the phenomenon of adverse selection and its consequences (see, for example, Crocker and Snow, 1986; Chiappori and Salanié, 2000; Abbring et al., 2003; Cohen and Siegelman, 2009; Gatzert et al., 2012).

${ }^{19}$ See, for example, Borch (1984).

${ }^{20}$ See, for example, Finkelstein et al. (2009)

${ }^{21}$ Rees and Wambach (2008).
} 
risk-averse customers take out adequate insurance cover (p. 45). ${ }^{21}$ Furthermore, surveys on price fairness presented, for example, by Homburg et al. ${ }^{22}$ conclude that an apparent motive for customer fairness implies a higher willingness to buy. If policyholders perceive premiums and benefits as fair and justified, they are more willing to accept the premiums determined by the insurer. Several authors discuss the so-called "propitious selection" theory where highly risk-avoiding consumers both reduce the hazard and purchase insurance, while less risk-averse customers are less willing to buy insurance voluntarily (Hemenway, p. 1064). ${ }^{23}$ The main difference with the phenomenon of adverse selection described by Akerlof ${ }^{24}$ is that customers can actively influence their risk behaviour. Therefore, customers who avoid high risk are targeted to reduce the hazard $\left(H_{e m e n w a y}{ }^{23,25}\right.$ ). Thomas (p. 129) ${ }^{26}$ justifies the principle of propitious selection where customer demand for insurance is linked with lower risk rather than higher risk.

Customer segmentation into groups plays an important role in risk selection in the insurance industry (p. 508). ${ }^{27}$ From an economic point of view, the principle of premium differentiation is introduced according to actuarial equal treatment of policyholders. The Pareto optimum describes a competitive equilibrium if every single relevant cost or utility factor has its market price (p. 942). ${ }^{28} \mathrm{~A}$ ban on risk-rating factors proscribes the use of available information and leads to suboptimal pricing. Accordingly, similar risks require an identical calculation of insurance premiums, while differing risks are to be treated with differentiation. ${ }^{29}$ Individual premiums assure that each policyholder finances his own expected loss or the expected loss of his customer segment. Furthermore, the resulting differentiated premiums per segment are essential for insurance companies to ensure the premium-independent composition of their portfolio, as well as to be efficient and competitive in the market (p. 21). ${ }^{30}$ Ebner $^{8}$ concludes that it is precisely through differentiated prices that higher advantages for both the customer and the insurer can be achieved.

A distinction is made between two forms of premium calculation for policyholders. The primary premium differentiation takes place upon signing of the contract: Pricing is based on "objective" and a priori-determined attributes, for example, in motor insurance, the type of car or motor power (p. 91). ${ }^{31}$ Secondary premium differentiation is carried out after a loss has occurred, that is, based on the experience of the insurer with the specific risk. The

${ }^{22}$ Homburg et al. (2005).

${ }^{23}$ Hemenway (1990).

${ }^{24}$ Akerlof (1970).

25 The phenomenon of adverse selection is due to hidden information; moral hazard, by contrast, is due to hidden action (see Cohen and Siegelman, 2009, p. 28). Moral hazard describes the excessive risk-taking behaviour of individuals and, thus, the increase in the overall risk level. Such behaviour occurs when the policyholder is more willing to take a risk and raise his claim/damage probability because of the knowledge that the insurer will assume responsibility for the costs in the event of a covered claim. Shavell (1979) describes the phenomenon of moral hazard in insurance pricing in detail in his paper.

${ }^{26}$ Thomas (2007).

${ }^{27}$ Brilmayer et al. (1979).

28 Arrow (1963).

${ }^{29}$ See, for example, Jannott (1994).

${ }^{30}$ Groupe Consultatif Actuariel Européen (2011).

${ }^{31}$ See Meyer-Kahlen (1988). 
individual "subjective" differences between risks within a risk group are calculated ex post, that is, in the form of premium adjustments based on individual claims records of the previous year, for example, in motor insurance, through a system of discounts and surcharges (p. 91). ${ }^{31}$ For the insurance industry, it is irrelevant if the risk criteria used are linked to causality. It is important that the criteria be reasonably stable over a sufficiently long period and correlated. ${ }^{32}$

A recent industry survey of all business lines ${ }^{33}$ shows that insurance companies have so far received very few complaints regarding policyholder discrimination on the basis of differentiated premiums. Since 2007, 51 per cent of the surveyed insurance companies have had no complaints, while 21 per cent have had fewer than five cases per year and only 3 per cent have had between five and nine complaints per year (p. 96). ${ }^{33}$ Most of these complaints concern life insurance and annuity products $(23$ per cent), private health insurance (19 per cent) and motor insurance (15 per cent) (p. 106). ${ }^{33}$ Fifty per cent of all complaints concerned refusal to provide services, 38 per cent concerned exclusions and restrictions, and 32 per cent involved prohibitively expensive premiums (p. 107). ${ }^{33}$ The complaints mainly relate to the criteria of age ( 42 per cent of all filings), disability ( 38 per cent) and ethnic origin (16 per cent) (p. 108). ${ }^{33}$ The low number of complaints is mainly explained by the appropriate legal framework in the EU. However, it is not clear if it is not simply the result of a lack of knowledge on the part of the public regarding anti-discrimination legislation.

\section{Regulatory point of view}

Since 2004, national regulations on gender discrimination have to be compatible with the Gender Directive and the specific conditions of its Article 5(2). However, until the end of 2012, EU Member States used the gender-related risk-rating factor according to national law in different ways (pp. 6-7). ${ }^{6}$ The Guidelines on the Application of the Gender Directive state that "all [EU] Member States currently allow gender differentiation for at least one type of insurance" (para. 3). ${ }^{6}$ Article 5(2) of the Gender Directive was only applied in EU Member States which had not already previously implemented gender-neutral tariffing into national legislation (para. 23). ${ }^{34}$ Accordingly, the principle of non-discrimination was applied "similarly" in EU Member States, but not "identically".

The starting point for the limitation of differentiated premium calculation in the European insurance industry was Council Directive 2000/43/EC, which abolished discrimination based on racial and ethnic origin. ${ }^{35}$ Schiek (p. 241) ${ }^{12}$ explains in detail how several market surveys demonstrate that financial institutions in Germany denied access to banking services to certain nationals in the 1990s. Furthermore, the German Federal Insurance Supervisory Office $^{36}$ forbade discrimination against foreigners in motor insurance. Before that, various insurers required an additional premium based on the risk criterion of the "foreigner".

The legislator takes precedence over the applicable insurance laws to protect individual rights (see also Ebner ${ }^{8}$ ). The Commission of the EC argued in its "Proposal for a Council Directive implementing the principle of equal treatment of women and men in the access to and supply of goods and services" that "equal treatment for women and men is a

\footnotetext{
${ }^{32}$ ABI (2010, p. 13).

${ }^{33}$ Civic Consulting (2010a).

${ }^{34}$ Kokott (2010).

${ }^{35}$ See Council of the EU (2000a).

${ }^{36}$ German Federal Insurance Supervisory Office (1995).
} 
fundamental right and $[\ldots]$ the freedom to set tariffs must be subject to that right. The separation of men and women into different pools leads to an unjustified difference of treatment $[\ldots]$. The practice must be judged to be discriminatory and the legislator should therefore take action to prohibit it" (see, pp. 7-8). ${ }^{5}$ Based on the ban on the gender criterion, the different positions of equality become apparent (p. 193). ${ }^{16}$ Discrimination in pricing is an illustration of the tension between the differentiation of existing legal discrimination law, based on the principle of human rights and the principal of equality between individuals on the one hand, and the principle of actuarial fairness and equality on the other hand.

\section{Ethical point of view}

Aristotle's formula is the basis for the principle of formal justice and can therefore also provide the basis for fair prices. Risk-based premium differentiation aims to treat situations similarly and price risks identically if they are comparable from a risk assessment perspective. The principle of formal justice is the requirement to treat comparable situations equally and non-comparable situations unequally, unless such treatment is objectively justified, that is, treating equals equally. ${ }^{37}$ Apart from formal equality there is substantive equality. "Substantive equality requires that the roots of inequality be identified, the goal of equality of opportunity be established, and that a legal mechanism be established that will achieve this goal in a principled way" (p. 2). ${ }^{38}$ That is, for example, to achieve substantive equality in insurance pricing, the use of the risk-rating factor motherhood is prohibited. ${ }^{39}$

Actuarial pricing is based on statistical data. The assessment of risk is carried out on the basis of personal customer characteristics which are not always obvious. Hence, insurance companies use criteria that are easy to identify and strongly linked with the target criterion. From an economic point of view, this seems efficient; from an ethical point of view, it may be critical. Doing so results in a generalisation, and specific individual cases are not taken into account. Hence, particular cases cannot be assessed individually and partial discrimination may occur (p. 17). ${ }^{40}$ Thus, treating individuals equally is a challenge within insurance portfolios.

The insurance industry uses price differentiation factors to determine the fair price for insurance products. Some are innate factors (for example, age, racial/ethnic origin, gender) or "given" (for example, health status), and others are endogenous criteria (for example, availability of garage parking in motor insurance). The central question is the comparability of different risk features with regard to actuarial calculations. In this context, some features are more influenceable (for example, smoking habits) than others, such as the gender criterion, which is inextricably linked with the person and represents an immutable attribute: "In addition, a person's gender, unlike, for instance, his age, is not subject to any natural changes" (para. 50). ${ }^{34}$ Because the assessment of comparability is time-dependent, the question of who judges comparability, what the comparison is based on, and which differences are considered to be legally relevant is crucial. The regulator issues anti-discrimination rulings for individuals who are negatively affected by law. Society - in our case the consumer-has to discuss the power of the state's influence (see the section "Insurance industry's point of view"). This is in the scope of the following analysis where the customer perception of risk factors will be analysed.

${ }^{37}$ Koller (2001).

${ }^{38}$ Centre for Equality Rights in Accommodation (CERA) (2013).

39 See, for example, Tobler (2005).

${ }^{40}$ See Britz (2008). 


\section{Customer perception of risk factors}

Various surveys focus on the customers views regarding differentiated premiums in the insurance industry. For example, the above-mentioned survey by Homburg et $a .^{22}$ concludes that consumers are more willing to pay if premiums are fair. A study by Civic Consulting ${ }^{33}$ focuses on complaints about price differentiation criteria that have reached independent arbitration committees. We observe that in most analyses similar to those by Homburg et al. ${ }^{22}$ and Civic Consulting ${ }^{33}$, no customers are directly questioned. Thus, the purpose of this section is to introduce our consumer survey and present the results obtained regarding the customers acceptance of price differentiation factors in the insurers pricing process.

\section{Survey description}

The survey was conducted in five European countries about four key insurance products focusing on several price differentiation criteria. The questionnaire was designed to determine consumers' acceptance of various differentiation criteria on the basis of practical examples. A detailed description of that questionnaire can be found in the Appendix.

The survey focused on the insurance product categories motor, annuity, life and health. In each of these product lines, a selection of the most relevant differentiation criteria is considered in Part I of the survey (see Appendix). For motor insurance, the criteria considered are the customer's age, the make of car, mileage and the customer's gender. For annuity insurance, the consumer's income, health status, smoker status and gender are taken into account. For life insurance, we look at the policyholder's age, body mass index (BMI), hobby and gender, while for health insurance, age, health status and gender are observed.

The poll was carried out in summer 2011 across the United Kingdom $(n=1,003$ retained respondents), Germany $(n=1,040)$, France $(n=1,014)$, Italy $(n=1,013)$ and Switzerland $(n=1,038)$, comprising a total of 5,108 questionnaires answered. The inquiry is representative for the local population structure by age and gender in each country. Respondents graded the four criteria presented in each product line on a scale from 1 to 5 ( $1=$ do not agree, $5=$ agree completely).

\section{Presentation of survey results and discussion}

Perceptions of the use of price differentiation criteria in the insurance industry, and the degree of importance attributed to it, vary according to the nationality and gender of the respondents. Significant differences are observable with respect to different countries, product lines and genders. Table 1 shows the descriptive statistics of the survey results and indicates the average appreciation rating for the different survey criteria in both gender groups in each of the countries considered, as well as the average standard deviation and significant differences between the mean values. Asterisks $(* *, *)$ are used to point out the significance levels between both gender groups within a country, letters (A, a) show significant differences between countries.

Differences among countries When analysing the reactions to the various risk attributes, two groups of countries emerge, each of which evaluates the factors differently. The first group includes the respondents in the United Kingdom (U.K.), who mostly perceive individual insurance pricing as fair and justified. In comparison to the other four countries, 
Table 1 Descriptive statistics of survey results: Acceptance of differentiation criteria

\begin{tabular}{|c|c|c|c|c|c|c|c|c|c|c|c|c|}
\hline \multirow[b]{3}{*}{$n$} & \multicolumn{2}{|c|}{ United Kingdom } & \multicolumn{2}{|c|}{ Germany } & \multicolumn{2}{|c|}{ France } & \multicolumn{2}{|c|}{ Italy } & \multicolumn{2}{|c|}{ Switzerland } & \multicolumn{2}{|c|}{ Overall (all countries) } \\
\hline & Female & Male & Female & Male & Female & Male & Female & Male & Female & Male & Female & Male \\
\hline & 516 & 487 & 518 & 522 & 517 & 497 & 510 & 503 & 520 & 518 & 2581 & 2527 \\
\hline \multicolumn{13}{|l|}{ Motor } \\
\hline \multirow[t]{2}{*}{ Age } & $3.64(1.12)$ & $3.88(1.09)$ & $3.15(1.15)$ & $3.54(1.19)$ & $3.03(1.35)$ & $3.16(1.34)$ & $3.25(1.16)$ & $3.60(1.15)$ & $3.15(1.24)$ & $3.28(1.28)$ & $3.24(1.22)$ & $3.49(1.24)$ \\
\hline & \multicolumn{2}{|c|}{$* * \mathrm{BCDE}$} & \multicolumn{2}{|c|}{$* * \mathrm{ACe}$} & \multicolumn{2}{|c|}{ ABDe } & \multicolumn{2}{|c|}{$* * \mathrm{ACE}$} & \multicolumn{2}{|c|}{$\mathrm{AbcD}$} & \multicolumn{2}{|c|}{$* *$} \\
\hline \multirow[t]{2}{*}{ Make } & $3.30(1.07)$ & $3.47(1.09)$ & $3.01(1.12)$ & $3.08(1.22)$ & $3.30(1.20)$ & $3.43(1.29)$ & $3.05(1.14)$ & $3.14(1.22)$ & $3.06(1.18)$ & $3.15(1.23)$ & $3.14(1.15)$ & $3.25(1.22)$ \\
\hline & \multicolumn{2}{|c|}{$* * \mathrm{BDE}$} & \multicolumn{2}{|c|}{$\mathrm{AC}$} & \multicolumn{2}{|c|}{ BDE } & \multicolumn{2}{|c|}{$\mathrm{AC}$} & \multicolumn{2}{|c|}{$\mathrm{AC}$} & \multicolumn{2}{|c|}{$* *$} \\
\hline \multirow[t]{2}{*}{ Kilometres } & $3.52(1.08)$ & $3.65(1.14)$ & $3.32(1.21)$ & $3.46(1.24)$ & $3.42(1.38)$ & $3.44(1.34)$ & $3.32(1.20)$ & $3.60(1.17)$ & $2.99(1.31)$ & $3.05(1.36)$ & $3.31(1.25)$ & $3.44(1.27)$ \\
\hline & \multicolumn{2}{|c|}{$\mathrm{BCdE}$} & \multicolumn{2}{|c|}{ ACDE } & \multicolumn{2}{|c|}{$\mathrm{AE}$} & \multicolumn{2}{|c|}{$* * \mathrm{aE}$} & \multicolumn{2}{|c|}{$\mathrm{ABCD}$} & $*$ & * \\
\hline Gender & $3.80(1.05)$ & $3.87(1.12)$ & $3.25(1.15)$ & $3.24(1.20)$ & $3.18(1.35)$ & $2.82(1.34)$ & $3.10(1.21)$ & $2.92(1.23)$ & $3.27(1.21)$ & $3.07(1.32)$ & $3.32(1.22)$ & $3.18(1.30)$ \\
\hline & $\mathrm{BC}$ & $\mathrm{DE}$ & $\mathrm{AC}$ & & & $3 \mathrm{E}$ & $* \mathrm{~A}$ & $\mathrm{BE}$ & $* A$ & $\mathrm{CD}$ & * & $*$ \\
\hline Annuity & & & & & & & & & & & & \\
\hline Income & $2.80(1.24)$ & $3.13(1.26)$ & $3.39(1.24)$ & $3.40(1.31)$ & $3.19(1.38)$ & $3.33(1.39)$ & $2.83(1.29)$ & $3.15(1.31)$ & $3.35(1.32)$ & $3.55(1.33)$ & $3.11(1.32)$ & $3.32(1.33)$ \\
\hline & $* * \mathrm{~B}$ & $\mathrm{CE}$ & $\mathrm{Ac}$ & & $\mathrm{Ab}$ & $\mathrm{DE}$ & $* * \mathrm{~B}$ & $\mathrm{CE}$ & $* A$ & CD & * & $*$ \\
\hline Health & $2.69(1.03)$ & $2.76(1.12)$ & $2.12(1.02)$ & $2.20(1.10)$ & $1.90(1.00)$ & $2.04(1.06)$ & $2.26(1.02)$ & $2.28(1.10)$ & $2.00(0.96)$ & $2.09(1.00)$ & $2.19(1.04)$ & $2.27(1.11)$ \\
\hline & BC & DE & $\mathrm{Ac}$ & & $* A$ & $\mathrm{BD}$ & $\mathrm{Ab}$ & $\mathrm{CE}$ & $\mathrm{Ab}$ & & * & 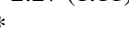 \\
\hline Smoker & $2.83(1.23)$ & $3.02(1.27)$ & $2.30(1.17)$ & $2.38(1.24)$ & $2.30(1.18)$ & $2.55(1.38)$ & $2.52(1.14)$ & $2.78(1.25)$ & $2.30(1.16)$ & $2.48(1.35)$ & $2.45(1.19)$ & $2.64(1.32)$ \\
\hline & $* \mathrm{BC}$ & $\mathrm{DE}$ & $\mathrm{A}$ & & & $\mathrm{AD}$ & $* * \mathrm{~A}$ & $\mathrm{BCE}$ & $* \mathrm{~A}$ & & * & $*$ \\
\hline Gender & $2.18(1.01)$ & $2.48(1.16)$ & $1.99(1.00)$ & $2.22(1.13)$ & $1.77(0.96)$ & $2.08(1.11)$ & $2.06(1.06)$ & $2.26(1.10)$ & $1.99(0.96)$ & $2.15(1.11)$ & $2.00(1.01)$ & $2.23(1.13)$ \\
\hline & $* * \mathrm{~B}$ & $\mathrm{CDE}$ & $* *$ & & $* * \mathrm{~A}$ & $\mathrm{BDE}$ & $\mathrm{A}$ & & $* A$ & & & * \\
\hline Life & & & & & & & & & & & & \\
\hline Age & $3.61(1.03)$ & $3.80(1.05)$ & $3.58(1.03)$ & $3.79(1.05)$ & $3.35(1.26)$ & 3.67 (1.17) & $3.03(1.15)$ & $3.35(1.13)$ & $3.34(1.11)$ & $3.50(1.13)$ & $3.38(1.14)$ & $3.62(1.12)$ \\
\hline & $\mathrm{Cl}$ & & $* * \mathrm{C}$ & $\mathrm{DE}$ & $* *$ & BD & $* * \mathrm{~A}$ & $\mathrm{BCE}$ & $* \mathrm{~A}$ & $\mathrm{BD}$ & & * \\
\hline BMI & $3.43(1.09)$ & $3.55(1.14)$ & $2.85(1.19)$ & $3.04(1.25)$ & $2.41(1.26)$ & $2.81(1.32)$ & $2.57(1.16)$ & $3.02(1.21)$ & $2.82(1.26)$ & $3.00(1.26)$ & $2.82(1.24)$ & $3.08(1.26)$ \\
\hline & $\mathrm{BC}$ & $\mathrm{DE}$ & $* \mathrm{~A}$ & $\mathrm{CD}$ & $* * \mathrm{~A}$ & BDE & $\mathrm{AB}$ & $\mathrm{Ce}$ & $* * A$ & $\mathrm{Cd}$ & * & * \\
\hline Hobby & $3.91(0.97)$ & $3.97(1.05)$ & $3.50(1.20)$ & $3.58(1.19)$ & $3.25(1.37)$ & $3.26(1.37)$ & $3.48(1.14)$ & $3.75(1.14)$ & $3.35(1.23)$ & $3.44(1.30)$ & $3.50(1.21)$ & $3.60(1.24)$ \\
\hline & $\mathrm{BC}$ & DE & $\mathrm{AC}$ & & $\mathrm{AB}$ & & $\mathrm{AC}$ & CE & $* * \mathrm{~A}$ & $\mathrm{BcD}$ & $*$ & * \\
\hline Gender & $3.37(1.04)$ & $3.37(1.10)$ & $3.09(1.07)$ & $3.02(1.12)$ & $2.95(1.29)$ & $2.70(1.26)$ & $2.83(1.17)$ & $3.11(1.14)$ & $2.91(1.16)$ & $2.74(1.19)$ & $3.03(1.16)$ & $2.99(1.19)$ \\
\hline & BC & & $\mathrm{AC}$ & & $* *$ & & $* *$ & $\mathrm{AcE}$ & $* \mathrm{~A}$ & $\mathrm{BD}$ & & \\
\hline
\end{tabular}




\begin{tabular}{|c|c|c|c|c|c|c|c|c|c|c|c|c|}
\hline \multirow[b]{3}{*}{$n$} & \multicolumn{2}{|c|}{ United Kingdom } & \multicolumn{2}{|c|}{ Germany } & \multicolumn{2}{|c|}{ France } & \multicolumn{2}{|c|}{ Italy } & \multicolumn{2}{|c|}{ Switzerland } & \multicolumn{2}{|c|}{ Overall (all countries) } \\
\hline & Female & Male & Female & Male & Female & Male & Female & Male & Female & Male & Female & Male \\
\hline & 516 & 487 & 518 & 522 & 517 & 497 & 510 & 503 & 520 & 518 & 2581 & 2527 \\
\hline \multicolumn{13}{|l|}{ Health } \\
\hline \multirow[t]{2}{*}{ Age } & $3.45(0.94)$ & $3.60(0.92)$ & $3.03(1.01)$ & $3.16(1.11)$ & $3.11(1.19)$ & $3.18(1.20)$ & $3.08(1.00)$ & $3.29(1.04)$ & $3.06(1.15)$ & $3.20(1.19)$ & $3.15(1.07)$ & $3.28(1.11)$ \\
\hline & \multicolumn{2}{|c|}{$* \mathrm{BCDE}$} & \multicolumn{2}{|c|}{ Ad } & \multicolumn{2}{|c|}{$\mathrm{A}$} & \multicolumn{2}{|c|}{$\mathrm{Ab}$} & \multicolumn{2}{|c|}{$* * \mathrm{~A}$} & \multicolumn{2}{|c|}{$* *$} \\
\hline \multirow[t]{2}{*}{ Health } & $3.67(0.92)$ & $3.78(0.97)$ & $2.96(1.03)$ & $3.05(1.08)$ & $2.48(1.20)$ & $2.69(1.23)$ & $2.77(1.17)$ & $3.02(1.19)$ & $2.75(1.12)$ & $2.81(1.16)$ & $2.93(1.16)$ & $3.06(1.19)$ \\
\hline & \multicolumn{2}{|c|}{$* * \mathrm{BCDE}$} & \multicolumn{2}{|c|}{ ACEd } & \multicolumn{2}{|c|}{$* * \mathrm{ABDE}$} & \multicolumn{2}{|c|}{$\mathrm{AbCe}$} & \multicolumn{2}{|c|}{$* * \mathrm{ABCd}$} & \multicolumn{2}{|c|}{$* *$} \\
\hline \multirow[t]{2}{*}{ Gender Social } & $2.82(0.90)$ & $2.69(0.94)$ & $2.70(1.10)$ & $2.53(1.19)$ & $2.61(1.22)$ & $2.43(1.18)$ & $2.98(1.08)$ & $2.73(1.07)$ & $2.71(1.24)$ & $2.54(1.22)$ & $2.76(1.12)$ & $2.58(1.13)$ \\
\hline & \multicolumn{2}{|c|}{$* \mathrm{BCdE}$} & \multicolumn{2}{|c|}{$* \mathrm{AD}$} & \multicolumn{2}{|c|}{$* \mathrm{AD}$} & \multicolumn{2}{|c|}{$\mathrm{aBCE}$} & \multicolumn{2}{|c|}{$* * \mathrm{AD}$} & \multicolumn{2}{|c|}{$* *$} \\
\hline \multirow[t]{2}{*}{ Gender } & $2.30(1.09)$ & $3.03(1.10)$ & $1.99(1.02)$ & $2.61(1.20)$ & $1.80(1.02)$ & $2.40(1.29)$ & $2.27(1.18)$ & $2.65(1.18)$ & $2.17(1.19)$ & $2.66(1.30)$ & $2.11(1.12)$ & $2.67(1.23)$ \\
\hline & \multicolumn{2}{|c|}{$\mathrm{BCDE}$} & \multicolumn{2}{|c|}{$* * \mathrm{ACDe}$} & \multicolumn{2}{|c|}{$* * \mathrm{ABDE}$} & \multicolumn{2}{|c|}{$\mathrm{ABC}$} & \multicolumn{2}{|c|}{$* * \mathrm{AbC}$} & \multicolumn{2}{|c|}{$* *$} \\
\hline Overall & $3.21(1.05)$ & $3.38(1.10)$ & $2.89(1.11)$ & $3.02(1.18)$ & $2.75(1.23)$ & $2.87(1.27)$ & $2.84(1.14)$ & $3.04(1.17)$ & $2.83(1.18)$ & $2.92(1.23)$ & $2.90(1.16)$ & $3.04(1.21)$ \\
\hline
\end{tabular}

Notes: *or lowercase letters denote significance at the 5 per cent level.

**or capital letters at the 1 per cent level.

Reported values denote the average and the standard deviation (given in parentheses) of the survey results for each risk factor considered and for both gender groups (female, male) in each country. The grades are based on a five-point scale: $1=$ do not agree, $5=$ agree completely (see also the survey description in the Appendix). The risk factors are grouped by product line (motor, annuity, life, health). The number $n$ denotes the number of respondents in each country-gender group. The significance of difference is given within gender groups in each country (denoted by stars) and between countries (denoted with letters). The letters refer to the countries in the order presented, that is, A=United Kingdom, B=Germany, and so on. 
respondents from the U.K. show the highest acceptance on average of all attributes (average: female $=3.21$, male $=3.38$ ). Furthermore, respondents in the U.K. have the highest acceptance rate in almost all product lines (14 out of the 16 attributes surveyed), regardless of the respondent's gender. The difference is particularly remarkable when compared with France, where the average acceptance rates are roughly half a point lower (2.75 and 2.87, respectively). Hence, French respondents constitute the core members of the second group: independent of their gender, they are less approving of the use of individual risk factors for differentiated pricing. This finding is also indicated by the overall value in each country (see bottom line in Table 1). Similar to the U.K., responses in France reveal extreme survey results. The majority of the respondents in France do not approve of the use of several individual risk characteristics (average rate below 3.0; consider, for example, gender or health criteria in annuity insurance and the gender criterion for health insurance, where the average values are $1.77,1.90$ and 1.80 , respectively). In comparison to the other countries, France has the lowest acceptance of risk factors, especially for annuity, life and private health products. Establishing prices based on gender differentiation is perceived as unfair in France, in absolute terms (lowest acceptance rates for annuity and health) and relatively when compared with the U.K. results.

It should be noted that the social policy of each country may have a considerable impact and thus may have clearly influenced the respondents' attitudes towards risk factors. On the one hand, the U.K. can be characterised as a liberal welfare state, where resources are allocated through market forces and the state merely establishes the basic rules and infrastructure for basic social security. ${ }^{41}$ On the other hand, France can be considered a corporate welfare state with a well-developed social and subsidising system. The U.K. model is similar to the one in Switzerland with regard to individual attributes and is particularly obvious in the use of income as a pricing criterion for annuity insurance premiums, which Swiss men seem to perceive as fair (average rate of 3.55).

Differences among lines of insurance When considering the acceptance rates of risk differentiation factors in the four surveyed product lines, the highest acceptance is found in motor insurance (average overall acceptance rate of 3.30), followed by term life insurance (3.25). In private health insurance (2.82) and annuity insurance (2.53), risk differentiation is less accepted. The risk criterion age has the highest customer agreement overall and thus in almost all countries across the four key insurance products. The highest acceptance rate for the use of age is observed for motor insurance (average overall acceptance rate for both genders of 3.37) and the lowest for private health insurance (3.22). However, in the latter case, the rate is still above the neutral level of 3 . The gender criterion is accepted the least in almost all product lines, in particular for annuity (2.12) and private health insurance (2.39). For motor and term life insurance, the acceptance rate is around 3.0 or higher (3.25 and 3.01, respectively).

The tendency of the two country groups is also reflected in the significance of the differences in the various product lines. Different reactions in all products can be found, with more pronounced differences between the U.K. rates and those of the other four countries. The U.K. responses were significantly different from the responses from any other country, except for the following pricing criteria: the make of the policyholder's car for motor insurance (not

\footnotetext{
${ }^{41}$ See, for example, Esping-Andersen (1990).
} 
significantly different from France), income for annuity insurance (not significantly different from Italy) and age for life insurance (not significantly different from Germany).

Differences between gender groups The analysis of differences in the response behaviour of the two genders reveals a heterogeneous picture. On the one hand, no gender-specific significant differences were found in the U.K. in the ratings of all pricing criteria for life insurance, or in France with respect to all the motor insurance pricing criteria, or in Italy with respect to health insurance. On the other hand, male and female respondents in Switzerland offer significantly different ratings of all risk attributes for life and health insurance. In between these extremes, where significant differences appear for all attributes of a product, about half of all ratings of risk factors reveal significant gender-specific response behaviour. The overall analysis of all countries demonstrates significant differences between the answers of men and women regarding the use of gender as a pricing criterion for life insurance, and health status as a pricing criterion for annuity insurance.

Correlation analysis We want to deepen our analysis by conducting an additional correlation analysis. We examine whether there is a correlation among the various surveyed requested risk classification criteria. This allows us to assess whether the acceptance level of a given attribute is linked to the acceptance level of another attribute.

In the following we briefly outline the correlation of the different attributes' appreciation. By considering the correlation of the rating of individual risk criteria, it is apparent that some attributes are more closely correlated than others. The highest correlation in acceptance is found between the rating of the risk criteria age and gender for motor insurance (Pearson correlation coefficient $\rho=0.42$ ). Hence, respondents favourable to the use of the age criterion also advocate the use of gender in price differentiation. Further correlations include the use of health status and age for health insurance $(\rho=0.40)$, and BMI and gender $(\rho=0.33)$ or BMI and hobby $(\rho=0.33)$ for life insurance.

Summary of survey results Our analysis shows that the majority of respondents in most countries accept the use of premium differentiation criteria for insurance pricing. More specifically, the risk factor age is the most accepted risk criterion across all countries for motor, life and health insurance. The risk criteria of the policyholder's personal hobby and age for life insurance as well as income for annuity insurance are also well accepted by the respondents. The gender criterion in motor insurance and the health status for private health insurance are judged most acceptable, especially by respondents from the U.K.

The greatest differences among the risk criteria examined are observed for health insurance. The use of the criteria age or health status is considered less discriminatory than the use of gender. This is particularly evident when analysing the survey results of respondents in France or the U.K. Generally speaking, the gender criterion is least accepted in pricing, apart from motor insurance. This can be seen particularly well when ranking the ratings in the different product lines: in most cases, the gender criterion receives the least favourable rating. However, since the ratings are based on a scale in which a rating of 3 corresponds to the neutral position, and the average ratings are concentrated around that neutral position, our results indicate that consumers do not consider the gender criterion as 
completely unacceptable. To summarise, most consumers accept gender-differentiated calculations when asked about their general acceptance of price differentiation criteria. Overall we also note that customers from the gender group that pays less premium or gets higher benefits in a particular product present higher acceptance levels (see Table 1, for example, in motor, annuity and health insurance where these differences are significant).

\section{The case of gender in insurance pricing}

In countries and product lines where gender differentiation is or was not prohibited, pricing differences are observed and the gender-specific differences are highly relevant. The gender criterion constitutes an important element in actuarial calculations. This is justified by a statistically significant difference in life expectancy between men and women with a relevant impact on mortality tables (p. 8). ${ }^{42}$ Further, males and females have significantly different average loss probabilities for given types of insurance policies, because, for example, they behave differently. However, an overview that we outline below demonstrates that the use of the risk-rating factor gender according to national law varied from country to country (before December 2012). We discuss the degrees to which consumers accept gender-specific differences in premiums. Finally, we expand on the possible (long-term) implications of the ECJ ruling and the definite ban on the gender criterion for individual insurance pricing.

\section{Use of gender in different countries and product lines}

The use of the gender criterion played an important role in the calculation of risk premiums and actuarial pricing (p. 19). ${ }^{43}$ Primarily in the four business lines considered above-life and pension insurance as well as motor and private health insurance-the gender criterion was very important for pricing. Demonstrable statistical differences in the claims are observed between men and women. Such differences concern pricing criteria, such as the difference in average life expectancy for life and annuity insurance, different driving behaviour for motor insurance, and different lifestyles as well as different inclinations to use medical services for private health insurance (pp. 5, 10-11). ${ }^{43}$ A study by Oxera ${ }^{42}$ illustrates the need for premium differentiation and the role of the gender criterion. Genderspecific premiums reflected the objective risk of policyholders. Dawkins (p. 1) ${ }^{44}$ argues that the motivation for using gender as a criterion for actuarial calculation is the same as for all criteria: to improve the efficiency of pricing.

The EU ruling follows the fact that the European Commission has concluded from several survey analyses that sex is not the main determining factor for life expectancy (p. 6). ${ }^{5}$ Thus, gender-specific differences in prices are always disadvantageous to either one gender group or the other. Gender-specific insurance premiums have been allowed in all 27 countries of the EU (pp. 6-7) 6 -including the countries in the consumer survey presented in the section "Customer perception of risk factors". The underwriter compensates for different risk levels

\footnotetext{
${ }^{42}$ Oxera (2011)

${ }^{43}$ See, for example, Society of Actuaries in Ireland (2004).

${ }^{44}$ Dawkins (2011).
} 
336

by charging different premiums based on differences in loss probabilities and magnitudes for a given insurance product.

According to Article 5(1) of the Gender Directive, "the use of sex as a factor in the calculation of premiums and benefits for the purpose of insurance and related financial services shall not result in differences in individuals' premiums and benefits" after 21 December 2007 (p. 41). ${ }^{1}$ The Gender Directive was implemented in national law after having been passed unanimously by all EU Member States and the European Parliament in 2004. Some EU countries have decided "before 21 December 2007 to permit proportionate differences in individuals' premiums and benefits where the use of sex is a determining factor in the assessment of risk based on relevant and accurate actuarial and statistical data" (p. 41). ${ }^{1}$ The insurer's pricing process is carried out on the basis of differentiation in risk groups using several risk characteristics.

In private health insurance, health-care costs are closely correlated with gender, since higher rates of sickness affect the costs of women until the age of 50. Up to about this age, the rates of hospitalisation are higher for men. ${ }^{45}$ Article 5(3) of the Gender Directive states that "in any event, costs related to pregnancy and maternity shall not result in differences in individuals' premiums and benefits" (p. 41). ${ }^{1}$ Especially in social health insurance, the costs of pregnancy and motherhood are distributed equally between genders, so that everybody is covered at the same price (p. 66). ${ }^{46}$ However, in private health insurance, three risk factors are used for the actuarial calculation: health status, age at the beginning of the contract and gender of the policyholder (p. 234). ${ }^{47}$ Often female policyholders have to pay much higher prices than men. Similar arguments apply to life insurance contracts. Premiums are calculated on the basis of statistical life expectancy and mortality tables (p. 9). ${ }^{46}$ Men have higher mortality rates than women at all ages. Among other factors, behavioural, biological and socio-economical differences result in gender-specific differences in mortality. Thus, in general, men had to pay higher rates for their term life insurance than women of the same age (p. 9). ${ }^{46}$ The gender criterion was also extensively used in annuity pricing. Because the life expectancy for women is on average five years longer than for men, their longer lifespan results in a longer average annuity period in old age, and therefore a higher present value of total annuity payments. ${ }^{48}$ Thus, women had to pay more for their insurance policy because of the longer average period during which benefits are claimed. For motor insurance, the gender risk factor is strongly linked to the age of the policyholder (p. 220). ${ }^{49}$ Male drivers are likely to make more expensive claims and have accidents more frequently, even if mileage is taken into account (p. 41). ${ }^{50}$ The average claims costs for an 18-year-old man may be twice as much as those for women (p. 107). ${ }^{51}$ Therefore, young men had to pay considerably more for their motor insurance.

There was a long tradition of using gender as a risk factor in the pricing of insurance, particularly in the five countries studied most closely in our analysis. The gender criterion was used for premium calculation in the four insurance products considered (p. 6). ${ }^{6}$

\footnotetext{
45 ABI (2010, p. 24).

${ }^{46}$ Civic Consulting (2010b).

${ }^{47}$ Riedel (2006).

${ }^{48}$ ABI (2010, p. 32).

${ }^{49}$ Kelly and Nielson (2006).

50 Arvidsson (2010).

${ }^{51}$ Civic Consulting (2010c).
} 
However, there were several national restrictions on gender-based pricing prior to the ECJ judgement and as a result of the Gender Directive. National law in several EU countries limited the use of the gender criterion for insurance products: In the U.K., for example, while gender has been used universally by insurers as a pricing factor, restrictions are defined in the Sex Discrimination Act of 1975, amended in 2008. ${ }^{52}$ That Act covers policies that enter into effect on or after 6 April 2008 (p. 4). ${ }^{53}$ In Germany, almost all major insurance companies have used the gender criterion. Gender-neutral tariffs had only been adopted previously for a few insurance classes. Such is the case, for example, for tax-privileged pensions, that is, Riester pensions (p. 141). ${ }^{33}$ However, the subsidisation results in the gender-neutral annuity product being priced more attractively for male customers (p. 21). ${ }^{42}$ The General Treatment Act, for example, restricts unequal premiums based on pregnancy in private health insurance. In France, the Penal Code, the Insurance Code and Act 78-17 of January 1978 relating to data, files and freedoms, amended in August 2004, include restrictions on the use of risk factors. In Italy, the Gender Directive was implemented by Legislative Decree 198/2006. Other restrictions are included in Italy's ISVAP Regulations of 30 May 2009 and Law 40/ 2007, the Bersani Law, which allows young drivers to take out their first policy in the same bonus-malus category as their parents (p. 154). ${ }^{33}$ In Switzerland, various risk criteria were examined regarding discrimination, but not based on gender. The Insurance Contract Act is now being thoroughly revised. The judgement of the ECJ is not legally binding for Switzerland and has no direct effect on insurance companies with activities in the Swiss market (p. 159). ${ }^{54}$ However, a new debate on gender justice could follow the decision of the ECJ. Previous parliamentary initiatives in this context have failed, so far, in Switzerland due to the resistance of the National Council (p. 159). ${ }^{54}$

\section{Customer perspective}

\section{Survey description}

The second part of our survey introduced in the section "Customer perception of risk factors" focused on the four key insurance products and their gender-specific price differences (see also Appendix, Section 2). In that part, specific examples of prices for each gender group in each product line were provided to the participants. The respondents then rated those price differences on a scale from 1 to 4 , where 1 means the "difference is too high" and 4 means the "difference is acceptable". In each product, we chose an exemplary male and female customer and their relevant market premium offered by one of the largest insurance companies. In each country, we considered the same premium levels and converted the values for the convenience of the respondents at the exchange rates applicable on the date of the survey. Consumers' assessment of price differences allows us to draw conclusions about the level of price sensitivity of customers with regard to gender differentiation. The results are reported in Table 2.

\section{Presentation of survey results and discussion}

Let us first recall-as an introduction to the acceptance of the risk criterion gender in the pricing of insurance products - the approval rates regarding the use of the gender criterion

${ }^{52}$ ABI (2010, p. 9).

53 Pinsent Masons LLP (2011).

${ }^{54}$ Pärli (2011). 
Table 2 Descriptive statistics of survey results: Acceptance of price differentiation

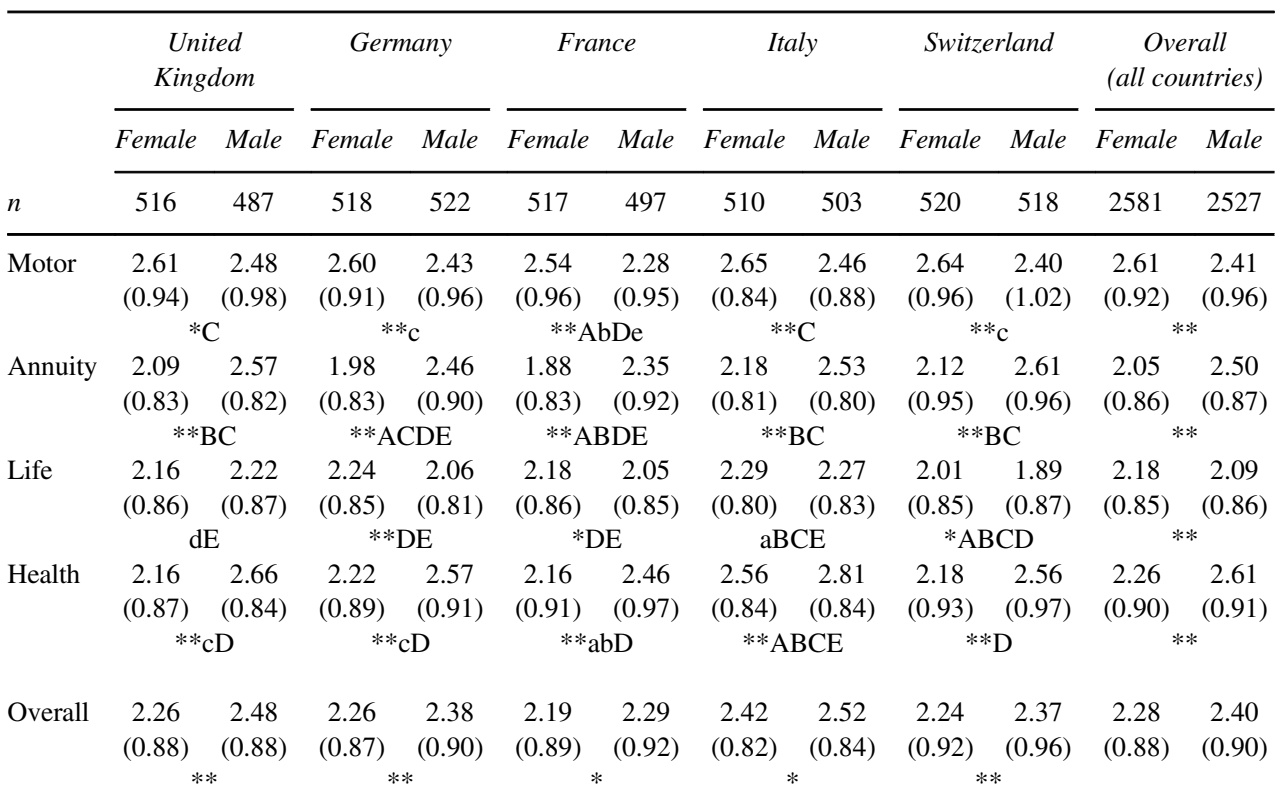

Notes: * or lowercase letters denote signific at the 5 per cent level.

** or capital letters at the 1 per cent level.

Reported values denote the average and the standard deviation (given in parentheses) of the survey results for each product line considered and for both gender groups (female, male) in each country. The grades are based on a fourpoint scale: $1=$ difference is too high, $4=$ difference is acceptable (see also the survey description in the Appendix). The number $n$ denotes the number of respondents in each country-gender group. The significance of difference is given within gender groups in each country (denoted by stars) and between countries (denoted with letters). The letters refer to the countries in the order presented, that is, $\mathrm{A}=\mathrm{United}$ Kingdom, $\mathrm{B}=\mathrm{Germany}$, and so on.

presented in the section "Customer perception of risk factors" (see Table 1). The highest acceptance for the use of the gender criterion is observed for motor insurance (overall acceptance rating of 3.25), followed by life insurance (3.01), health insurance (2.39) and annuity insurance (2.12). Thus, especially for health and annuity insurance, the use of the gender criterion is not well accepted (values below the neutral level of 3), or customers are less aware of the importance of the use of the gender criterion. ${ }^{55}$

55 Furthermore, the fact that the use of gender is favourable for women in respect to annuities, not favourable for women in case of a term or whole life insurance contract, plays a role in the response. However, accordingly, the gender criterion should be rejected for every line of insurance because, for the motor and private health insurance lines, there are also differences in the premiums for both genders. In addition, it should be noted that the gender criterion is only the second most important risk factor after the age criterion in actuarial pricing of annuity and life insurance (see Oxera, ${ }^{42}$ p. 9 ). Thus, the age criterion has a more significant impact on mortality, for example, due to increased illness and accidents, than the gender criterion and is classified as more relevant for insurance pricing (see Civic Consulting, ${ }^{33}$ p. 59). 
Differences among lines of insurance The results of the second part of the survey reported in Table 2 demonstrate low acceptance of gender-based price differences in the respondent countries. The respondents judge the price differences as too high (values below the neutral level of 2.5). That is especially true for term life insurance (average overall acceptance rate of 2.14) and annuity insurance (2.28). For private health (2.44) and motor insurance (2.51), price differentiation based on gender is less controversial. The average overall acceptance rate of 2.34 is below the neutral level of 2.5 .

Differences between gender groups Broken down by gender, the acceptance rates of price differentiation for men are higher for private health (overall male acceptance rate of 2.61) and annuity insurance (2.50). The opposite is true of female respondents for motor (2.61) and term life insurance (2.18), where women accept price differences. The different response pattern is due to the large differences in compensation/benefits paid out for the insured event which are favourable, depending on the insurance line, to one or the other gender group. For example, men tend to accept price differences in private health insurance, where premiums for women are higher, while female respondents accept the price difference to their advantage for motor insurance. Very significant differences between the answers of both genders are observable in all product lines and all five countries. The gender-specific difference is simply not significant for term life insurance among respondents in the U.K. and Italy.

Differences among countries When analysing the response behaviour by country, the lowest acceptance of gender-based price differences is observable in France (average acceptance rate of 2.24). The majority of Italian male respondents accept the gender-based price difference for private health insurance (2.81). By contrast, the lowest acceptance rate is found for annuity insurance among French female respondents (1.88). The tendency of a different response behaviour among French respondents compared with the other countries is also reflected when comparing the significance levels of differences in the various product lines. Especially for motor insurance, the responses from France are found to be significantly different from those of the other four countries.

Correlation analysis Finally, we present the findings from a correlation analysis of the ratings for the acceptance level of the gender attribute (Part I of the survey) and the acceptance level of the corresponding price difference due to gender (Part II). The highest correlation is found for motor insurance with a Pearson correlation coefficient of $\rho=0.44$. This is followed by health insurance at $\rho=0.35$, life insurance at $\rho=0.32$ and annuity insurance with $\rho=0.13$. Thus, respondents show the greatest acceptance of a gender-based pricing difference for motor insurance. However, the general relevance and the explanation of main cost drivers to customers ${ }^{56}$ still seem to play a central role in the insurance industry.

\footnotetext{
${ }^{56}$ For example, claims adjustment expenses, administrative costs of risk assessment and underwriting as well as operational costs, like acquisition and portfolio commissions, see, for example, Farny (2011, pp. 46-47).
} 
Summary of survey results Our analysis of gender-based price differences shows that the majority of respondents in most countries judge these differences differently in the various lines of insurance. Price differences based on the gender criterion are less accepted in term life, annuity and private health insurance. Since the rating is based on a scale in which a rate of 2.5 corresponds to a neutral position, our results indicate that consumers tend to consider the effective gender-based price differences too high (overall acceptance rate of 2.34). Only in motor insurance does the average approval rate reach 2.5 points. Furthermore, similarly to the general acceptance of the gender criterion, consumers of the group profiting from premium differentiation (that is, paying a lower premium) still disapprove the amount of the price difference, though to a lesser extent. Summing up, consumers accept the use of the risk criterion gender in premium calculations when asked about their general acceptance of differentiation criteria (see the results in the section "Customer perception of risk factors" and the summary of survey results). However, the amount of the premium differences is not accepted by consumers as soon as specific premium examples are given.

\section{Possible implications of the ban on gender-based discrimination}

The ECJ has issued a ruling definitively banning the use of the gender criterion in actuarial calculations for individual prices. The ruling may have important consequences for the insurance industry and customers in the EU. Irrespective of the stakeholder's perspective and of the definition of discrimination "a ban on a relevant risk-rating factor such as gender cannot be achieved without costs" ${ }^{57}$ In this section, a number of implications are discussed. Possible consumer behaviour and potential responses from market players are outlined as well as possible further regulatory interventions. The implications of the definitive ban on genderbased discrimination are extensive for the insurance industry and may have a strong economic and legal impact on the individual product offering and pricing.

\section{Customer reactions and adverse selection effects}

Following the ban on gender-based discrimination, insurers and policyholders will have unequal access to information on gender characteristics, which may result in further adverse selection effects, as described by Akerlof.$^{24}$ Even if the gender characteristic of customers is taken into account by the insurer at the overall portfolio level, adverse selection effects are enhanced, whenever one group of policyholders has to pay an increased risk premium for a statistically lower risk (p. 8). ${ }^{58}$ This may have an impact on the demand for insurance products, at least for markets with low price inelasticity. In the extreme situation of full adverse selection, the subsidising policyholder group (second group) will no longer take out any insurance policies at all (if not compulsory or critical, see Thiery and Van Schoubroeck, p. 199 $)^{16}$ and thus in the long run the portfolio may be formed solely by the members of the first group, which has a higher claims expectancy. Prices will be adjusted accordingly and finally, only one price-the one for the more costly policyholder group-will remain. Furthermore, cross-subsidies between insurance groups of different genders are implied. The higher claims expectancy of the one group will be distributed to all other policyholders of the second group.

\footnotetext{
${ }^{57}$ ABI (2010, p. 36).

58 Owiwo (2011).
} 
The resulting decrease in customer demand may lead to a future limitation on the product offering and to a possible withdrawal by competitors from certain less profitable product lines. Once insurance solutions have been abandoned, substitute products may become attractive. Forms of self-insurance or mutual/investment funds for retirement arrangements may be preferred. Overall, the insurance market may decrease in size along with the quality of the insurance benefits. These effects may be stronger in the annuity and life insurance market, as such insurance is not compulsory, unlike motor insurance, for example (p. 36). ${ }^{42}$ On the other hand, for compulsory insurance lines (for example, motor insurance), further moral hazard behaviour may occur, meaning that excessive risks may be taken and that the average risk level may increase.

Finally, let us note that the ban on gender-based discrimination may also give rise to positive reactions from consumers. For example, customers may perceive the insurance industry as ethically and socially better or even more consumer-friendly-especially in light of the fact that effective gender-specific price differences are less accepted.

\section{Possible reactions by the insurance industry}

From an insurance industry perspective, several new challenges arise. The invalidity of Article 5(2) of the Gender Directive has considerable consequences for product development and actuarial calculation. Owing to unisex pricing, it is no longer possible to use gender as a risk criterion for individual pricing of policies. In accordance with the provisions of paragraph 17 of the Guidelines on the Application of the Gender Directive, "the use of risk factors which might be correlated with gender [...], as long as they are true risk factors in their own right" is allowed (para. 17). ${ }^{6}$ Thus, a calculation of the risk of damage cannot only take place at the level of the insurance portfolio (including the consideration of gender). However, the definitive premium only represents a mixed tariff (which may be a weighted average by the gender-mix in the portfolio). The results are adverse selection of policyholders and hybrid product tariffs (p. 9) ${ }^{30}$ Because the use of the gender criterion is no longer allowed, market distortion will result. Cross-subsidisation from high-risk policyholders to low-risk policyholders will result.

To achieve an equitable spread of risks in their portfolio, insurers may provide increased direct incentives to specific target customers. Strategic marketing may then include genderspecific sales campaigns (for example, in magazines with a strong gender-specific readership) and gender-specific individual product-offerings (para. 14). ${ }^{6}$ In addition, insurance companies may make increasing use of risk criteria which are correlated with gender if they are independent risk factors, for example, the size of a car engine for motor insurance (para. 17). ${ }^{6}$ The available customer data will be increasingly analysed and correlated risk criteria developed without having to establish a direct reference to gender. Furthermore, the importance of the use of other risk factors independent of the gender criterion may increase, for example, for motor insurance, the length of the customer's driving experience, vehicle safety features and maybe (in the near future), driver tracking technology. These effects lead to a reduction of adverse selection, as the pricing will be based on several risk criteria (not including gender) that may end up mapping risks more precisely than today's use of the gender criterion alone. We will keep in mind, however, even if this price ends up being more equitable, that one factor (namely gender) still remains unused. The transaction costs as well as the administration expenses and the risk premium may increase for insurance companies (p. 8). ${ }^{58}$ 
An additional opportunity for portfolio selection is through the modification of the sales commission and through incentives to sales staff, for example, higher commissions for acquiring customers from among the lower-risk gender (p. 2). ${ }^{59}$ The result can be a deliberate exclusion of customers in specific tariffs (for example, private insurance, where acceptance of customers is not compulsory under applicable law) and hence, an increase in the adverse selection phenomenon (p. 9) ${ }^{58,60}$ The termination option of existing contracts emphasises this effect. Current customers may terminate their old contract and conclude a new one with the unisex tariffs if the latter are more favourable (depending on the product line and the individual gender) (see also para. 81). ${ }^{34}$ In particular, contracts that can generally be terminated at short notice may imply relatively fast reactions (see, for example, yearly contracts for motor or private health insurance policies) and changes in the insurers' portfolio composition (p. 2). ${ }^{59}$ Brokers and their corresponding commission scheme for contract renewals may accelerate this trend. Hence, additional transaction costs will be paid by switching policyholders until a new equilibrium with one unisex price is finally established in the market (p. 9). ${ }^{58}$ An increased premium level in unisex tariffs could merely cushion this effect. The aforementioned study by Oxera ${ }^{42}$ predicts that the gender-neutral uniform tariff could result in higher premiums for one or the other gender depending on product lines. On the one hand, a 40-year-old woman may have to pay over 30 per cent more for life insurance, while a 20-year-old woman could have to pay 11 per cent more for motor insurance. On the other hand, a 50-year-old man could pay 5 per cent less for annuity insurance (p. 25). ${ }^{42,61}$

In an insufficiently competitive oligopolistic market, higher average prices due to marketsharing agreements may result. Gender-neutral premiums may be higher than the accumulated previous rates weighted for men and women because of adverse selection. In part, this is because it is more difficult to calculate an alternative risk criterion by collecting and evaluating data regarding the social and economic circumstances of an insured person and a risk premium may be levelled. Furthermore, those risk factors can change over time and, therefore, may indicate a higher uncertainty for insurers (para. 66). ${ }^{34} \mathrm{In}$ addition, in the aforementioned preferred group of policyholders, a "levelling down effect" may be observed and, in the previously disadvantaged group, a "levelling up effect".

The contemplated effects depend, for example, on the amount of the premium, the benefit differences, the transparency of premium calculation for policyholders and finally on the action that customers take to switch tariffs. It is expected that some customers will buy fewer insurance policies due to higher premiums. Policyholders with a better-than-average risk profile may churn, and the average risk may increase because of adverse selection (p. 8). ${ }^{58}$ To cover the average risk probability and the uncertainty, insurance companies could adopt premium loading or raise the safety margin.

59 Deutsche Rück (2011).

${ }^{60}$ Thiery and Van Schoubroeck ${ }^{16}$ (pp. 196-197) express scepticism regarding the subsidy-aversion phenomenon. In particular, the doubts concern the manageability of individual risk factors, the causal link between potential risk factors and the risk itself as well as the enhanced welfare effects of the use of different risk criteria in actuarial pricing and the increasing costs for developing alternative risk criteria.

${ }^{61}$ With regard to the above one-sided approach, further research could indeed analyse the impact of unisex tariffs. Several papers and reports concern the experience of unisex tariffing in different countries and lines of insurance (see, for example, Wallace, 1984; Brown, 1995; Nova Scotia Insurance Review Board, 2004; Curry and O'Connell, 2004). 


\section{Regulatory intervention}

The gender-neutral premium calculation requires major changes on the part of insurance companies. It may be expected that alternative risk criteria or combinations of risk criteria will take more precedence, for example, "risk factors which might be correlated with gender, as long as they are true risk factors in their own right", for example for motor insurance, car engine size (para. 17). ${ }^{6}$ It therefore follows that a prohibition of the use of the single gender criterion does not automatically result in gender neutrality in insurance pricing. ${ }^{62}$ Such reactions from the insurance industry may lead to further governmental or regulatory intervention in pricing and product development (p. 36). ${ }^{46}$ At the moment, pursuant to Paragraph 18 of the Guidelines on the Application of the Gender Directive only the use of the gender criterion is prohibited (p. 4). ${ }^{6}$ In November 2000, the EU Council adopted Directive 2000/78/EC for establishing a general framework for equal treatment in employment and occupation independent, for example, of someone's age (Art. 1). ${ }^{63}$ Furthermore, the Commission of the EC decided in July 2008 in a proposal for a Council Directive to implement "the principle of equal treatment between persons irrespective of religion or belief, disability, age or sexual orientation"(p. 13) ${ }^{64}$ outside the field of employment. The ban on other differentiation criteria, for example age or health status, may result. Each intervention in the pricing mechanism may lead to market distortions and may impair the principle of (statistically) fair contributions and benefits.

\section{Conclusion}

The remaining practice of actuarial calculation based on the gender criterion was examined by the ECJ in 2011. In this paper, we briefly summarise the framework of the ECJ ruling and the importance of risk differentiation from different stakeholder perspectives. We provide an overview on the use of several risk criteria in various countries and product lines and illustrate the implications of the ban on gender-based differentiation for the insurance industry.

The results of our consumer survey are presented in two parts. First, we examine the acceptance of differentiation criteria. The study shows that respondents in most countries accept the use of risk differentiation. The gender criterion is least accepted in pricing, closely followed by age. Especially for annuity and private health insurance, the gender criterion is less accepted than other criteria. Second, we examine the acceptance of gender-specific price differences. The results illustrate that using gender criteria within the business lines health, annuity and term life insurance is not accepted by consumers as soon as the amount of prevalent price differences is compared side-by-side.

The implications of a prohibition on gender-based discrimination are substantial for actuarial calculation. As a result of cross-subsidies between insurance groups and adverse selection effects, premiums may increase. A withdrawal by insurance companies and a limitation of product offering are possible. Further regulatory intervention may intensify these aspects.

\footnotetext{
${ }^{62}$ ABI (2010, p. 40).

${ }^{63}$ Council of the EU (2000b).

${ }^{64}$ Commission of the EC (2008).
} 


\section{Acknowledgements}

The authors gratefully acknowledge financial support by Kessler \& Co AG. In addition, the authors would like to thank two anonymous referees for their helpful suggestions and comments on an earlier draft of the manuscript.

\section{References}

Abbring, J.H., Heckman, J.J., Chiappori, P.-A. and Pinquet, J. (2003) 'Adverse selection and moral hazard in insurance: Can dynamic data help to distinguish?' Journal of the European Economic Association 1(2-3): $512-521$

Akerlof, G. (1970) 'The market for 'lemons': Quality uncertainty and the market mechanism', The Quarterly Journal of Economics 84(3): 488-500.

Arrow, K.J. (1963) 'Uncertainty and the welfare economics of medical care', The American Economic Review 53(5): 941-973.

Arvidsson, S. (2010) 'Essays on asymmetric information in the automobile insurance market', Ph.D. thesis, Örebro University.

Association of British Insurers (ABI) (2010) The Use of Gender in Insurance Pricing: Analysing the Impact of a Potential Ban on the Use of Gender as a Rating Factor, ABI Research Paper No. 24, London: Association of British Insurers.

Benston, G.J. (1982) 'The economics of gender discrimination in employee fringe benefits: Manhart revisited', The University of Chicago Law Review 49(2): 489-542.

Benston, G.J. (1983) 'Discrimination and economic efficiency in employee fringe benefits: A clarification of issues and a response to professors Brilmayer, Laycock, and Sullivan', The University of Chicago Law Review 50 (1): 250-279.

Borch, K. (1984) 'Equilibrium premiums in an insurance market', The Journal of Risk and Insurance 51(3): 468-476.

Borenstein, S. (1989) 'The economics of costly risk sorting in competitive insurance markets', International Review of Law and Economics 9(1): 25-39.

Brilmayer, L., Hekeler, R.W., Laycock, D. and Sullivan, T.A. (1980) 'Sex discrimination in employer-sponsored insurance plans: A legal and demographic analysis', The University of Chicago Law Review 47(3): 505-560.

Brilmayer, L., Laycock, D. and Sullivan, T.A. (1983) 'The efficient use of group averages as nondiscrimination: A rejoinder to professor Benston', The University of Chicao Law Review 50(1): 222-249.

Britz, G. (2008) Einzelfallgerechtigkeit versus Generalisierung: Verfassungsrechtliche Grenzen statistischer Diskriminierung, Tübingen: Mohr Siebeck.

Brown, R.L. (1995) 'Recent Canadian human rights decisions having an impact on gender-based risk classification systems', Journal of Actuarial Practice 3(1): 171-191.

Burri, S. and Prechal, S. (2010) EU Gender Equality Law: Update, 2010, Luxembourg: Office for Official Publications of the European Communities, from http://www.ec.europa.eu/justice/gender-equality/files/ dgjustice_eugenderequalitylaw_update_2010_final24february2011_en.pdf.

Buzzacchi, L. and Valletti, T. (2005) 'Strategic price discrimination in compulsory insurance markets', The Geneva Risk and Insurance Review 30(1): 71-97.

Centre for Equality Rights in Accommodation (CERA) (2008) Human Rights in Housing in Canada: An Advocate's Guide, p. 9, from http://www.equalityrights.org/cher/National\%20Guide\%20English\%20Final.pdf.

Chiappori, P.-A. and Salanie, B. (2000) 'Testing for asymmetric information in insurance markets', Journal of Political Economy 108(1): 56-78.

Christiansen, H. (1983) 'Equality and equilibrium: Weaknesses of the overlap argument for unisex pension plans', The Journal of Risk and Insurance 50(4): 670-680.

Civic Consulting (2010a) Study on the Use of Age, Disability, Sex, Religion or Belief, Racial or Ethnic Origin and Sexual Orientation in Financial Services, in Particular in the Insurance and Banking Sectors, Part I: Main Report, Technical Report, Brussels: European Commission.

Civic Consulting (2010b) Study on the Use of Age, Disability, Sex, Religion or Belief, Racial or Ethnic Origin and Sexual Orientation in Financial Services, in Particular in the Insurance and Banking Sectors, Part II: Country Reports, Technical Report, Brussels: European Commission. 
Civic Consulting (2010c) Study on the Use of Age, Disability, Sex, Religion or Belief, Racial or Ethnic Origin and Sexual Orientation in Financial Services, in Particular in the Insurance and Banking Sectors, Part III: Annexes, Technical Report, Brussels: European Commission.

Cohen, A. and Siegelman, P. (2009) Testing for adverse selection in insurance markets, National Bureau of Economic Research Working Paper No. 15586, Cambridge: NBER.

Commission of the EC (2003) Proposal for a Council Directive Implementing the Principle of Equal Treatment between Women and Men in the Access to and Supply of Goods and Services, EUR-Lex 52003 PC0657.

Commission of the EC (2008) Renewed Social Agenda: Opportunities, Access and Solidarity in 21st Century Europe, EUR-Lex 52008DC0412.

Council of the EC (1975) 'Council Directive 75/117/EEC', Official Journal of the European Communities L45: 19-20.

Council of the EU (2000a) 'Council Directive 2000/43/EC', Official Journal of the European Communities L180: $22-26$.

Council of the EU (2000b) 'Council Directive 2000/78/EC', Official Journal of the European Communities L303: $16-22$.

Council of the EU (2004) 'Council Directive 2004/113/EC', Official Journal of European Communities L373: $37-43$.

Crocker, K. and Snow, A. (1986) 'The efficiency effects of categorical discrimination in the insurance industry', Journal of Political Economy 94(2): 321-344.

Curry, C. and O'Connell, A. (2004) An analysis of unisex annuity rates, equal opportunities, Commission Working Paper No. 16.

Dawkins, R. (2011) Gender and Insurance Pricing, from http://www.europe-economics.com/blogpost/6/gender -and-insurance-pricing.htm.

Deutsche Rück (2011) 'Unisex: Absicherung von Schwankungen im Geschlechtermix', Daten.Fakten.Meinungen., No. 2/11, Düsseldorf: Deutsche Rückversicherung AG.

Ebner, M.D. (2010) Preispolitik in der Kompositversicherung. Karlsruhe: Verlag Versicherungswirtschaft.

Esping-Andersen, G. (1990) The Three Worlds of Welfare Capitalism, Princeton: Princeton University Press.

European Commission (2012) 'Guidelines on the application of Council Directive 2004/113/EC to insurance, in the light of the judgement the Court of Justice of the European Union in Case C-236/09 (Test-Achats)', Official Journal of the European Union C11: 1-11.

European Court of Justice (ECJ) (2011) Judgement of the Court, Case C-236/09.

Farny, D. (2011) Versicherungsbetriebslehre, 5th edition, Karlsruhe: Verlag Versicherungswirtschaft.

Finkelstein, A., Poterba, J. and Rothschild, C. (2009) 'Redistribution by insurance market regulation: Analyzing a ban on gender-based retirement annuities', Journal of Financial Economics 91(1): 38-58.

Ford, J. and Reifner, U. (1992) Banking for People: Social Banking and New Poverty Consumer Debts and Unemployment in Europe-National Reports, Berlin: Walter de Gruyter.

Gatzert, N., Hoermann, G. and Schmeiser, H. (2012) 'Optimal risk classification with an application to substandard annuities', North American Actuarial Journal 16(4): 462-486.

German Federal Insurance Supervisory Office (1995) BAV Rundschreiben 6/95: Motor Vehicle InsuranceDiscrimination Against Foreigners.

Groupe Consultatif Actuariel Européen (2011) Use of Age and Disability as Rating Factors in Insurance: Why Are They Used and What Would Be the Implications of Restricting Their Use?, position paper, December.

Hedges, B. (1977) 'Gender discrimination in pension plans: Comment', The Journal of Risk and Insurance 44(1): 141-144.

Hemenway, D. (1990) 'Propitious selection', The Quarterly Journal of Economics 105(4): 1063-1069.

Hickman, J. (1983) 'Pensions and sex', The Journal of Risk and Insurance 50(4): 681-687.

Homburg, C. and Koschate, N. (2005) 'Behavioral pricing-Forschung im Überblick, Teil 1: Grundlagen, Preisinformationsaufnahme und Preisinformationsbeurteilung', Zeitschrift für Betriebswirtschaft 75(4): 383-423.

Homburg, C., Koschate, N. and Hoyer, W.D. (2005) 'Do satisfied customers really pay more? A study of the relationship between customer satisfaction and willingness to pay', Journal of Marketing 69(2): 84-96.

Hoy, M. (1982) 'Categorizing risks in the insurance industry', The Quarterly Journal of Economics 97(2): 321-336. 
346

Jannott, E. (1994) Der Grundsatz der Gleichbehandlung in der Versicherungswirtschaft, in U. Hübner (ed.) Recht und Ökonomie der Versicherung: Festschrift für Egon Lorenz, Karlsruhe: Verlag Versicherungswirtschaft, pp. 341-362.

Kelly, M. and Nielson, N. (2006) ‘Age as a variable in insurance pricing and risk classification', The Geneva Papers on Risk and Insurance-Issues and Practice 31(2): 212-232.

Kimball, S.L. (1979) 'Reverse sex discrimination: Manhart', American Bar Foundation Research Journal 1979(1): 85-139.

Kimball, S.L. (1980) 'Reprise on Manhart', American Bar Foundation Research Journal 1980(4): 915-920.

Kokott, J. (2010) Opinion of Advocate General Kokott. Case C-236/09. Association Belge des Consommateurs Test-Achats ASBL and others.

Koller, P. (2001) Theorie des Rechts: Eine Einführung, 2nd edition, Wien: Bohlau Verlag.

Laycock, D. and Sullivan, T.A. (1981) 'Sex discirmination as "actuarial equality": A rejoinder to Kimball', American Bar Foundation Research Journal 6(1): 221-228.

Martin, G. (1977) 'Gender discrimination in pension plans: Author's reply', The Journal of Risk and Insurance 44(1): 145-149.

Martin, G. (1979) 'Gender discrimination in pension plans revisited: The results of court ordered implementation', The Journal of Risk and Insurance 46(4): 727-732.

Meyer-Kahlen, W. (1988) Bonus-/Malus-System, in D. Farny, E. Helten, P. Koch and R. Schmidt (eds) Handwörterbuch der Versicherung HdV, Karlsruhe: Verlag Versicherungswirtschaft, pp. 91-97.

Myers, R. (1977) 'Gender discrimination in pension plans: Further comment', The Journal of Risk and Insurance 44 (1): $144-145$.

Nova Scotia Insurance Review Board (2004) A Study Into the Use of Gender as a Rating Factor in Automobile Insurance in Nova Scotia, Province of Nova Scotia.

Owiwo (2011) Der Einfluss der Europäischen Union auf die Finanzierung der Gesundheitsversorgung in den Mitgliedstaaten, Technical Report November, Otto-Wolff-Institut fürWirtschaftsordnung (owiwo), Köln.

Oxera (2011) The Impact of a Ban on the Use of Gender in Insurance, Oxford: Oxera Consulting.

Pärli, K. (2011) Verbot geschlechtsspezifischer Prämien bei Versicherungsverträgen: Urteil des Europäischen Gerichtshofes vom 1. März 2011, Rs C-236/09 (Vorabentscheidungsverfahren), HAVE/REAS, 2:153-159.

Pinsent Masons LLP (2011) Gender Discrimination and Insurance, from http://www.out-law.com/page-9368.

Rees, R. and Wambach, A. (2008) 'The microeconomics of insurance', Microeconomics of Insurance, Foundations and Trends in Microeconomics 4(1-2): 1-163.

Riedel, O. (2006) 'Unisex tariffs in health insurance', The Geneva Papers on Risk and Insurance-Issues and Practice 31(2): 233-244.

Rothschild, M. and Stiglitz, J. (1976) 'Equilibrium in competitive insurance markets: An essay on the economics of imperfect information', The Quarterly Journal of Economics 90(4): 629-649.

Schiek, D. (2000) Differenzierte Gerechtigkeit: Diskriminierungsschutz und Vertragsrecht, Baden-Baden: Nomos Verlagsgesellschaft.

Schmidt, C. (1989) Die Frauenprämie in der privaten Krankenversicherung im Lichte des Gleichbehandlungsgrundsatzes, Ph.D. thesis, Saarbrücken.

Shavell, S. (1979) 'On moral hazard and insurance', The Quarterly Journal of Economics 93(4): 541-562.

Society of Actuaries in Ireland (2004) The Draft EU Directive on Equal Insurance Premiums for Men and Women, Society of Actuaries in Ireland, Dublin.

Thiery, Y. and Van Schoubroeck, C. (2006) 'Fairness and equality in insurance classification', The Geneva Papers on Risk and Insurance - Issues and Practice 31(2): 190-211.

Thomas, R.G. (2007) 'Some novel perspectives on risk classification', The Geneva Papers on Risk and Insurance-Issues and Practice 32(1): 105-132.

Tobler, C. (2005) Indirect Discrimination: A Case Study Into the Development of the Legal Concept of Indirect Discrimination Under EC Law, Antwerpen: Intersentia.

U.S. Supreme Court (1978) City of Los Angeles Department of Water and Power v. Manhart, 435 U.S. 702.

U.S. Supreme Court (1983) Arizona Governing Committee for Tax Deferred Annuity and Deferred Compensation Plans et al. v. Norris, 463 U.S. 1073.

Wallace, F.K. (1984) 'Unisex automobile rating: The Michigan experience', Journal of Insurance Regulation 3(2): 127-139.

Wang, S.S. (2000) 'A class of distortion operations for pricing financial and insurance risks', The Journal of Risk and Insurance 67(1): 15-36. 


\section{Appendix: Survey on price differentiation in insurance}

The online survey carried out in summer 2011 captured the consumers' opinion of five European countries comprising the United Kingdom, Germany, France, Italy and Switzerland. In each country a separate language version was defined including figures in the relevant currency. The following socio-demographic information was gathered from the respondents: gender, age, level of education, current job situation and household income. In each country, at least 1,000 responses were collected. The panel was representative in each country with regard to the criteria gender and age (18-65 years). The following sections reproduce the wording of the survey used in the United Kingdom (English version) and the corresponding scales for the responses. The first part of the questionnaire concerns the acceptance of differentiation criteria in general (Section 1) while the second part is about the acceptance of price differentiation with regard to gender (Section 2).

\section{Acceptance of differentiation criteria (survey Part I)}

Below are several statements about the four key insurance products. Please tell us how accurate you consider these statements to be. Please use the following five-point scale:

$1=\mathrm{I}$ do not agree

$2=$ fairly inaccurate

$3=$ neutral

$4=$ fairly true

$5=\mathrm{I}$ agree completely

\section{Motor insurance}

- Car drivers over the age of 50 incur fewer costs associated with car accidents from a statistical point of view. For this reason, older customers are justifiably charged a lower price in comparison to younger drivers.

- Customers with vehicles of specific makes are associated with higher administrative costs for the insurer (for example, a statistically higher number of calls to the call centre). Due to these additional costs, customers in this group pay a correspondingly higher price to avoid all customers being charged more.

- Vehicles used to drive more kilometres each year have a greater risk of damage. Customers who drive a fewer number of kilometres each year therefore receive a price discount in accordance with the average lower risk of damage.

- The accident rate among young men is significantly higher-with otherwise comparable conditions-compared to women of the same age. Accordingly, young men pay a higher price than young women.

\section{Annuity insurance}

- The average life expectancy of smokers is around 10 years lower than non-smokers. The statistically lower life expectancy justifies a shorter time span for annuity payments in old age, and therefore a lower price. 
- Policyholders with good and poor health have different life expectancies. Nevertheless, both groups receive the same annuity payments at the same price in old age.

- If women and men pay the same price for their annuity insurance over the same period of time, the annuity payments in old age should be the same for both genders. Differences in life expectancy and the resulting difference in the level of annuity payments should not be taken into consideration.

- People with a higher income statistically live longer than those with low incomes. When the insurer is establishing its prices, high-earning customers should pay higher prices for their annuity insurance than those with low incomes.

\section{Term life insurance}

- The life expectancy of women is on average five years higher than that of men. The lower probability of death for women of a certain age should be expressed in the form of lower prices compared to men of the same age.

- The mortality rates are strongly linked to the age of the individual: The probability of death among young people is much lower than among older individuals. The price of life insurance is significantly lower for young customers than older customers.

- The body mass index, which measures body weight in relationship to body size, is used by many insurers as an attribute when calculating their prices. Overweight people pay higher prices, as they have a statistically worse risk profile.

- The customer's hobbies have an influence on their risk of accidents or death. A customer who pursues a riskier type of sport (for example, combat sports) or a riskier hobby (for example, handling snakes) will therefore pay a higher price.

\section{Health insurance}

- Public health insurance as part of social insurance is the same for all policyholders, although the costs to be assumed are different depending on age and gender. These subsidisations between genders and age groups are appropriate in public insurance.

- Pregnancy and birth have an influence on higher health costs for women. In some countries, these health-specific costs of both genders are covered equally, that is, men subsidise the prices generated by women. In the case of private health insurance (for example, single bedrooms and treatment by the head physician at the hospital), women should pay higher prices than men.

- Depending on the age group, average health costs vary in private health insurance. For this reason, the prices are generally based on the age of the policyholder. This categorisation is a justifiable distribution of risks.

- Health levels and existing health problems are relevant when determining the risk profile of the customer. Justifiable pricing in private health insurance requires higher prices or exclusions in health cover for "bad" risks.

\section{Acceptance of price differentiation (survey Part II)}

On 1 March 2011, the ECJ decided that, from the end of 2012, insurance companies will no longer be permitted to apply gender as an attribute when establishing prices for their 
products. The basis for this decision is the equal rights of both genders before the Court. Below, we have listed examples about insurance prices for the four products assessed above, taking the differentiation of genders into account. Please assess the price differences provided as examples by considering whether you think the differences are acceptable. Please use the following scale:

$1=I$ think the difference is too high

$2=\mathrm{I}$ think the difference is slightly too high

$3=\mathrm{I}$ think the difference is fairly acceptable

$4=\mathrm{I}$ think the difference is acceptable

Motor insurance: The accident rate among young men is significantly higher-with otherwise comparable conditions - compared to women of the same age. The 22-year-old male driver pays on average 900 GBP each year, while a woman of the same age only pays 700 GBP.

Annuity insurance: Men and women have different life expectancies. For a lump sum payment of 90,000 GBP at the age of 55, a 65-year-old woman will receive 400 GBP on a monthly basis from the beginning of her retirement, while a man of the same age will receive 450 GBP.

Term life insurance: The life expectancy of women is higher than that of men. An insurance policy with the lump sum payment of $90,000 \mathrm{GBP}$ in the event of death costs $160 \mathrm{GBP}$ a year for a 40-year-old man and $110 \mathrm{GBP}$ for a woman of the same age.

Private health insurance (single-bed rooms and head physician treatment at the hospital): Pregnancy and birth have an influence on increasing health costs for women. Due to these costs associated with a specific gender, a 30-year-old woman will pay on average $80 \mathrm{GBP}$ per month, while a man of the same age will pay only $70 \mathrm{GBP}$.

\section{About the Authors}

Hato Schmeiser studied Business Administration at the University of Mannheim. After his doctoral degree and post-doctoral lecturer qualification ("Habilitation") in 2003 (Humboldt University, Berlin), he was appointed Professor for Insurance and Risk Management at the University of Münster. Since 2005, he has held the Chair for Risk Management and Insurance and is Managing Director of the Institute of Insurance Economics at the University of St. Gallen (Switzerland). His main research interests include individual financial planning, dynamic financial analysis, option pricing and regulation of financial firms.

Tina Störmer holds the degree of Master of Arts. She studied Management of Construction, Real Estate and Infrastructure at the Bauhaus University, Weimar (Germany) and International Relations at the Catholic University of Eichstätt-Ingolstadt (Germany). She currently is a $\mathrm{PhD}$ student and project manager at the Institute of Insurance Economics of the University of St. Gallen (Switzerland). Before, she was a candidate of the Management Programme Sales and Distribution of Allianz Deutschland AG. Her main research interest includes strategic insurance pricing with focus on risk differentiation and consumers acceptance. 
Joël Wagner is Assistant Professor of Risk Management and Insurance at the University of St. Gallen's Institute of Insurance Economics (Switzerland). He is also a member of the Steering Committee of the Profile Unit Responsible Corporate Competitiveness (ROCC). Prior to that, he was a consultant in the Financial Services and Insurance practice of the Boston Consulting Group. He holds a $\mathrm{PhD}$ in mathematics and an engineering degree in physics from the Swiss Federal Institute of Technology in Lausanne. His research interests include a range of topics in risk management and insurance with particular focus on recent developments in regulatory and reporting frameworks as well as the analysis of challenges in insurance. 